\title{
The Impact of Integrated Reporting on Analysts' Forecasts
}

\author{
Romy Bakker ${ }^{1}$, Georgios Georgakopoulos ${ }^{2}$, Virginia - Athanasia Sotiropoulou ${ }^{3}$, Kanellos S. Tountas ${ }^{4}$ \\ ${ }^{1}$ Amsterdam Business School, University of Amsterdam, Netherlands \\ ${ }^{2}$ Agricultural University of Athens, Greece \\ ${ }^{3}$ School of Economics and Business, University of Patras, Greece \\ ${ }^{4}$ Department of Economic Science, National and Kapodistrian University of Athens, Greece \\ Correspondence: Virginia - Athanasia Sotiropoulou, School of Economics and Business, University of Patras, \\ Greece. Tel: 306-976-878-125. E-mail: sotiropoulou.v.a@gmail.com, vsotiropoul@upatras.gr
}

Received: November 5, 2019

doi:10.5539/ijef.v12n1p76
Accepted: December 30, 2019 Online Published: December 31, 2019

URL: https://doi.org/10.5539/ijef.v12n1p76

\begin{abstract}
Shareholders are very interested in the relationship between Integrated Reporting and analyst forecast accuracy. Integrated Reporting is deemed to reduce information asymmetry between the company and shareholders. The purpose of this paper is to provide evidence on the relationship between Integrated Reporting and analyst forecast accuracy. Analyst forecast accuracy is examined for a global sample of companies that adopted Integrated Reporting, companies that get assurance on Integrated Reporting, companies that receive assurance on their integrated reports by one of the Big 4, and for a south african sample, companies that are mandated to use Integrated Reporting. Information for analysts' forecasts is retrieved from the $\mathrm{I} / \mathrm{B} / \mathrm{E} / \mathrm{S}$ database and information for Integrated Reporting is retrieved from the GRI Sustainability Disclosure Database. We do not find a significant impact of Integrated Reporting on analyst forecast errors. Similarly, attestation of the reports by bigger or smaller audit firms does not seem to affect analysts' forecast accuracy. In South Africa however, a positive impact on analysts' forecast accuracy is observed suggesting that the effect of mandatory integrated disclosures is important for analysts' forecasts.
\end{abstract}

Keywords: analyst forecast accuracy, Integrated Reporting, assurance on Integrated Reporting, Big 4 assurance on Integrated Reporting, mandatory Integrated Reporting

\section{Introduction}

Shareholders need information relative to current and future performance of firms. Integrated reports present financial and non-financial data and they give a more complete picture of the company and how it creates value in the short, medium and long term. The purpose of an integrated report is to provide details of a firm's strategy, risks, and their impact on the environment and society (International Integrated Reporting Council [IIRC], 2013b).

Agency theory (Jensen \& Meckling, 1976) postulates that when managers have more information than shareholders, they use it for their own interest. By disclosing financial and non-financial information the management of a company potentially reduces information asymmetry, investment risk and therefore the cost of capital.

In this light Cheng, Green, Conradie, Konishi, and Romi (2014) call for the examination of the impact of Integrated Reporting on capital markets. Integrated reports are considered to give extra insights to investors and analysts as they do not contain only financial data. Since analyst forecasts are used by investors to reduce risk in their investments, it is very important that these forecasts are credible and accurate. Prior studies indicate that non-financial information, (e.g. corporate responsibility reports), improves analyst forecast accuracy (Dhaliwal, Radhakrishnan, Tsang, \& Yang, 2012). Thus we would expect similar results for integrated reports.

Our research question is postulated thus as: "Does the implementation of Integrated Reporting result in higher analyst forecast accuracy?" and it is examined through four hypotheses looking into: the relation of forecast accuracy with Integrated Reporting; the relation of forecast accuracy with assurance on integrated reports; and the relation of forecast accuracy with mandatory Integrated Reporting.

Our paper proceeds as follow: In the next section we briefly discuss the literature review in relation to Integrated Reporting, capital market and analyst forecast accuracy. We then present our research hypotheses, data sample and 
empirical analysis. Finally, we discuss our findings, limitations of our work and areas for future research.

\section{Literature Review}

\subsection{Integrated Reporting}

In the past decade, global economy has become more knowledge-intensive and information-based depending much less on physical assets (Eccles \& Serafeim, 2014). Both shareholders and stakeholders demand more information on corporates, and as a result traditional financial reporting is not considered as being adequate anymore. Companies provide voluntary more information in their reports on environmental and social impacts, paying attention on non-financial disclosures (Dumay, Bernardi, Guthrie, \& Demartini, 2015).

These types of disclosures were initially provided into stand-alone environmental reports and subsequently into sustainability and corporate social responsibility (CSR) reports (Simnett, Vanstraelen, \& Chua, 2009; Cohen, Holder-Webb, Wood, \& Nath, 2012). However, these reports are not very helpful for investors as they cannot be linked to financial performance directly. This is because related information is rarely presented in the context of the organizational strategy and/or business model. Corporate reports need significant improvement in order to satisfy the needs of stakeholders and investors (Eccles \& Krzus, 2010; Eccles \& Serafeim, 2014).

Integrated Reporting was introduced by the International Integrated Reporting Council (IIRC) to enhance corporate reporting. IIRC consists of regulators, investors, companies, standard setters, accounting professionals and NGOs (IIRC, 2013b). The IIRC framework advocates the use of both financial and non-financial information and deviates substantially from traditional financial reporting with the purpose of an integrated report being able to provide a complete picture of the company in order to make the process of short, medium and long term value creation obvious and comprehensible to all interested users of corporate information (Barth, Cahan, Chen, \& Venter, 2017; Cheng et al., 2014; Humphrey, O'Dwyer, \& Unerman, 2017).

Integrated Reporting is deemed as having benefits that could impact the value of corporate reporting. It is perceived to reduce the clutter of current corporate reporting by promoting conciseness (Zhou, Simnett, \& Green, 2016). It discloses only the information that is material for the value-creating process by/in a company. Furthermore, integrated reports are coherent and wrestle to explain how strategy and operational aspects connect and how a firm is able to create and sustain value (IIRC, 2013b). Caglio, Melloni, and Perego (2019) investigate the mandatory implementation of Integrated Reporting in South Africa and they find that higher market valuation is related with readability of integrated reports. There is also an association between tone bias and less dispersion of analysts' forecasts and conciseness with higher stock liquidity, as well.

Integrating Reporting is voluntary in most countries. Reporting entities are free in the manner by which they can adopt Integrated Reporting and therefore they can decide themselves what to disclose and how to disclose it in their reports (Zhou et al., 2016). Due to this discretion, a great variation in the quality of integrated reports may arise. Pistoni, Songini and Bavagnoli (2018) find that the quality of integrated reports is low in general. In cases that Integrated Reporting is adopted, the appropriate framework is not fully implemented. Companies pay more attention to the form of integrated reports than the content. Managers do not reveal much information about the process of value creation, strategic priorities, business model and capital.

South Africa is the first country to incorporate Integrated Reporting in its listing rules. Companies listed at the Johannesburg Stock Exchange (JSE) are subject to the King Code on Corporate Governance (King III). King III obliges all listed companies to publish an integrated report or to publicly explain why they deviate (Institute of Directors Southern Africa, 2009). Related research (e.g. Zhou et al., 2016) indicates that mandatory implementation increases reported information quality. In contrast, when the implementation of Integrated Reporting is voluntary, a variation in the quality of the disclosures is observed, as companies include information that they consider important.

Since Integrated Reporting is only mandatory in South Africa, there are other ways to increase the quality of the report. One way is external assurance. Simnett et al. (2009) studied external assurance on sustainability reports. They find that companies that seek to enhance the credibility of their report and build their corporate reputation are more likely to have their sustainability reports assured. This implies that these reports have higher quality.

\subsection{The International Integrated Reporting Framework}

In 2013 the International Integrated Reporting Framework was published with the aim to explain to forward looking investors the process of value creation by companies in the short, medium and long term. Its purpose is to establish guiding principles and content that could be used to put together an integrated report and to explain the fundamental concepts therein. In specific, elements of the business model; value creation; and the capitals are presented and explained (IIRC, 2013). 
The business model is "the chosen system of inputs, business activities, outputs and outcomes that aims to create value over the short, medium and long term" (IIRC, 2013). Outputs are the products and services produced by the company. In the outputs are also included the waste and other by-products that create or erode value. The results from business activities and outputs are the outcomes which are the internal and external consequences from the use of capital. The business model uses inputs from the capitals, transforms the capitals through business activities and interactions to produce outputs and outcomes that, over the short, medium and long term, create or destroy value for the organization, its stakeholders, society, and the environment. Thus in order to assess the value creation of an entity one should consider the interdependencies between the entity's competitiveness and performance and the communities, stakeholders, supply chains and the natural environment.

The purpose of Integrated Reporting implementation is to point out those resources and relationships that affect the value creation activities of the company (Barth et al., 2017). Integrated Reporting enables investors to estimate investment risk, validate decisions and evaluate information relative to future corporate performance (IIRC, 2017).

\subsection{The Capital Market}

Analysts play a very important role in capital markets as they inform the investors about the value potential of organizations. Hence, analyst forecast accuracy has a significant impact on investors' decisions.

\subsubsection{Analyst Forecasts}

Financial analysts are the main information intermediaries in capital markets (Frankel, Kothari, \& Weber, 2006; Healy \& Palepu, 2001) with analyst forecasts deemed as having a large impact on investment decisions (Frankel et al., 2006). According to Healy and Palepu (2001) capital flows from an investor, directly or through financial intermediaries, to businesses; and information flows from businesses, directly or through information intermediaries, to the investors. Information is provided by companies to analysts in order to make their forecasts. Investors rely on the unbiased expectations of analysts about the future performance of the firms and they make their decisions then. Both public and private information is used by financial analysts in order to provide investors with information (Brown, Call, Clement, \& Sharp, 2015).

Previous research (Healy \& Palepu 2001; Gleason \& Lee, 2003) indicates that analysts' forecasts reduce information asymmetry between firms and financial stakeholders and hence, they add value to the capital market. Firms benefit from the reduction of information asymmetry in their turn since quality of disclosures increases as information asymmetry decreases, leading to lower investment risk and lower cost of capital (Dhaliwal, Li, Tsang, \& Yang, 2011; Zhou et al., 2016). Analyst forecasts also create incentives in the capital markets (Kasznik \& McNichols, 2002) to meet analyst expectations. Firms that eventually meet analysts' forecasts receive a premium in their share prices.

\subsubsection{Analyst Forecast Quality}

High quality analyst forecasts insinuate higher credibility and informative value to capital markets. The most common proxies for analyst forecast quality are analyst forecast accuracy and analyst forecast dispersion (Zhou et al., 2016). The reason of their extended use is that they imply a higher degree of certainty for firms' future earnings. In this paper we use analyst forecast accuracy measured as the error margin of financial analysts' forecasts. This is calculated as the difference between the forecasted value and the actual value of earnings deflated by the stock price. Thus forecasts with low errors and consequently high accuracy can be used to provide valuable information.

There are various factors that have an impact on analyst forecast accuracy such as reliability of numbers, industry knowledge, communication with management and comparability (Healy \& Palepu, 2001; Brown et al. 2015). Furthermore, forecast accuracy is also affected by the size of the company, its profitability, and its compliance with rules and regulations for reporting and the forecast horizon. Literature argues that it is more preferable to make the announcement of the forecast close to the earnings announcement date in order to avoid over-optimism (Healy \& Palepu, 2001; Brown et al. 2015).

\subsubsection{The Relation Between Integrated Reporting and Analyst Forecast Accuracy}

Agency theory addresses the issue of information asymmetry. In order to reduce information asymmetry stakeholders could monitor management's activities by utilising both financial and non-financial corporate disclosures (Healy \& Palepu, 2001). Analysts act as intermediaries between companies and capital markets and they are potentially able to reduce information asymmetry. However, information asymmetry is also detected between analysts and firms. Analysts use the information provided by firms and as a result when information asymmetry decreases, analysts can make more accurate forecasts. In a similar fashion voluntary disclosures can improve the information environment of a firm since analysts' understanding of an entity's potential also reduces information asymmetry (Beyer, Cohen, Lys, \& Walther, 2010). 
Research indicates that forecast accuracy and quality of disclosures are positively associated (Hope, 2003; Lang \& Lundholm, 1993; Plumlee, 2003). When quality of disclosures increases, analysts gain better insights about companies and they make more accurate projections (Hope, 2003; Lang \& Lundholm, 1993). Literature also indicates that analysts use both financial and non-financial information and that the latter (especially CSR reports) is very useful for their forecasts (Dhaliwal et al., 2011; Dhaliwal et al., 2012).

However, there are certain limitations. Analysts have cognitive limitations, which means they are not able to perfectly assess complex information due to lack of knowledge (Zhou et al., 2016). When the quality of information increases, the cost of processing information decreases and analysts are better able to include all material information in their forecasts (Lehavy, Li, \& Merkley, 2011). Less intelligible reports are negatively associated with analyst forecast accuracy (Lehavy et al., 2011). According to Plumlee (2003), complex changes to tax law have a negative impact on forecast accuracy. This stream of research explores the manner by which complex information, even of high quality, reduces analyst forecast accuracy. Rajgopal, Shevlin and Venkatachalam (2003) indicate that analysts tend to overlook material non-financial information due to 'information overload'.

The issue of information complexity can be solved by presenting the information in a more intelligible manner. The way disclosures are presented can change what users think of accounting information (Hodge, 2001; Kelton, Pennington, \& Tuttle, 2010; Koonce \& Mercer, 2005). Integrated Reporting is argued to differentiate from traditional financial reporting because of higher reporting quality. This is achieved through the integration and presentation of financial and non-financial information. Even though there is no new, value-relevant information the manner by which financial and non-financial information is presented in an alternative format could have thus a positive impact on analyst forecast accuracy.

\section{Hypotheses Development}

According to the previous literature we propose the following hypotheses:

$H_{I}$ : There is a positive relation between the use of integrated reports and the accuracy of analysts'forecasts.

The review of literature above, suggests that there are three processes that could potentially increase analyst forecast accuracy. First, forecast accuracy is increased by adding new information that contains value. As discussed, the information incorporated in integrated disclosures is about the firm's potential to create value in the short, medium and long term and that could be useful for analysts.

Second, analyst forecast accuracy is increased by reducing the information acquisitions costs and giving the analysts the opportunity to concentrate on their forecasts. The most significant guiding principles of Integrating Reporting that contribute to this are: materiality, conciseness and connectivity (IIRC, 2013b).

Third, an effective way to improve forecast accuracy is the enhanced presentation of the information. Integrated reports combine financial and non-financial information and as a result they provide information which is more complete to analyze.

$\mathrm{H}_{2}$ : There is a positive relation between external assurance of integrated reports and the accuracy of analysts' forecasts.

External auditors ensure that the financial reports of a firm comply with the guiding principles. Past studies (e.g. Pflugrath et al., 2011; Simnett et al., 2009) indicate that the information is more reliable when it is assured by an external independent party. The quality of information is increased and consequently analysts' forecasts are more credible as they receive an accurate image of firms' future potentials (Behn, Choi, \& Kang, 2008; Casey \& Grenier, 2015).

$H_{3}$ : There is a stronger impact of external assurance of integrated reports on the accuracy of analysts' forecasts when provided by a Big 4 audit firm.

Big 4 audit firms (Deloitte, PwC, EY and KPMG) are widely seen as providing higher quality assurance (e.g. Khurana \& Raman, 2004; Simnett et al., 2009). Therefore, the information quality is higher and that leads to more accurate analysts' forecasts.

$H_{4}$ : There is a positive relation between obligatory implementation of Integrated Reporting and the accuracy of analysts'forecasts.

South Africa is the only country where the use of integrated reports is mandatory on a use or explain basis. Previous research (Bernardi \& Stark, 2016) indicates that the mandatory implementation of Integrated Reporting in South Africa has increased the accuracy of analyst forecasts. The quality and the comparability of integrated reports are considered higher. Furthermore, companies that are obliged to issue integrated reports are familiar with 
the rules and thus they provide high-quality information that enhances analysts' forecasts.

\section{Methodology and Data Selection}

\subsection{Data Selection}

Table 1. Sample mutations

\begin{tabular}{lc}
\hline & Number of observations \\
\hline Observations in I/B/E/S database & 2914266 \\
Missing information or duplicates & -2836536 \\
Observations before merging & 77730 \\
No match with GRI database & -75076 \\
No match with Compustat Global database & -560 \\
Missing information or duplicates & -339 \\
Final sample & 1755 \\
\hline
\end{tabular}

Note. This table shows the mutations in the I/B/E/S database. The final sample consists of 1755 unique observations of 698 unique firms.

In this paper there is a combination of archival data on analyst forecast accuracy and on the implementation, assurance and obligatory issuance of Integrated Reporting. Since the International Integrated Reporting Framework was introduced in 2013 our dataset includes international listed public entities for the years 2013 to 2018.

The GRI Sustainability Disclosure Database is used in order to collect data for Integrated Reporting. The information provided includes global sustainability and integrated reports. Additionally, there is information therein on the assurance of the relevant reports and the providers of that attestation. For our fourth hypothesis, data from publicly listed companies in the JSE are used.

The Institutional Brokers Estimate System (I/B/E/S) database is used for data on analyst forecast accuracy and earnings. Data for the control variables and for financial information are collected also from I/B/E/S and from Compustat Global where applicable.

Our initial sample includes 1914266 observations from I/B/E/S. These are merged with data from the GRI Sustainability Database and Compustat. Company names are used as identifiers in order to match data on Integrated Reporting with data on analyst forecasts since the GRI Sustainability Disclosure Database does not include Cusip/Sedol codes. The merged dataset is then merged again with the Compustat Global Database based on Cusip/Sedol and gvkey. The final sample contains 1756 observations from 698 unique firms.

\subsection{Empirical Design}

\subsubsection{Dependent and Independent Variables}

An appropriate variable for measuring analyst forecast accuracy is the forecast error. This is used as the dependent variable. According to Lang and Lundholm (1996) forecast accuracy is the negative of the absolute value of analyst forecast error, deflated by stock price:

$$
\text { Forecast errort }=\left(\left|E P S_{t}-A F t\right|\right) / P t
$$

$\mathrm{EPS}_{\mathrm{t}}=$ Earnings per share in period $\mathrm{t}$.

$\mathrm{AF}_{\mathrm{t}}=$ Median analyst forecast of earnings per share in period $\mathrm{t} . \mathrm{P}_{\mathrm{t}}=$ Price per share in period $\mathrm{t}$.

For the first hypothesis the independent variable is Integrated Reporting. Integrating Reporting is a dummy variable that is equal to 1 if it is implemented.

For the second hypothesis the independent variable is Integrated Reporting with external assurance. The latter takes the value of 1 if external assurance is provided in integrated reports and 0 otherwise.

For the third hypothesis the independent variable is Integrated Reporting with external assurance by a Big 4 audit firm. This is again equal to 1 if external assurance is provided in integrated reports by a Big 4 audit firm.

For the fourth hypothesis the independent variable is mandatory implementation of Integrating Reporting. Since the implementation of Integrating Reporting is mandatory only in South Africa the dummy variable equals 1 if the implementation is indeed obligatory and 0 otherwise.

\subsubsection{Control Variables}

There are several external factors that can have an impact on analyst forecast accuracy. Five external factors are considered in our study. 
The first control variable is the size of the firm. Prior studies indicate that the size of the company has a positive impact on the accuracy of forecasts (Hope, 2003; Dhaliwal et al., 2012; Gleason \& Lee, 2003). Analysts receive more information from larger firms. We include the control variable SIZE in our analysis proxied by the natural logarithm of a company's total assets in U.S. dollars at the end of the year (Dhaliwal et al., 2012).

The second control variable is firm's losses. Hope (2003) argues that less profitable firms that have losses, have greater earnings volatility and therefore it is harder to make a forecast. LOSS is a dummy equal to 1 if the company has negative income and 0 otherwise.

The third control variable is analyst following. The greater the number of analysts that follow the firm and make forecasts, the higher the forecast accuracy. In this paper, FOLLOW is the natural logarithm of the number of analysts that follow the company during the year (Dhaliwal et al., 2012).

The fourth control variable is the forecast horizon which is the time between the forecast and the announcement of the actual value. The shorter the forecast horizon, the higher the analyst forecast accuracy. HORIZON is proxied by the median number of days between the earnings announcement date and forecast date for each firm each year (Dhaliwal et al., 2012).

The fifth control variable is IFRS compliance. Horton et al. (2009) and Dhaliwal et al. (2012) suggest that when IFRS are obligatory, analyst forecast accuracy is enhanced. IFRS is equal to 1 if the financial report of the company is in compliance with IFRS. An overview of all variables used in this study can be found in table 2 .

Table 2. Variable definitions

\begin{tabular}{|c|c|c|}
\hline Type & Code & Explanation \\
\hline DV & FERROR & orecast error - Absolute value of analyst forecast error, deflated by stock price for each firm each year. \\
\hline IV1 & IR & Integrated Reporting - Dummy variable equal to 1 if the firm issues an Integrated Report, and 0 otherwise. \\
\hline IV2 & ASSURIR & $\begin{array}{l}\text { External assurance on IR - Dummy variable equal to } 1 \text { if thefirm issues an integrated report and external assurance is } \\
\text { provided by a third party, and } 0 \text { otherwise. }\end{array}$ \\
\hline IV 3 & ASSURIR4 & $\begin{array}{l}\text { External assurance on IR provided by a Big } 4 \text { audit firm-Dummy variable equal to } 1 \text { if the firm issues an integrated } \\
\text { report and external assurance is provided by a Big } 4 \text { audit firm, and } 0 \text { otherwise. }\end{array}$ \\
\hline IV4 & MANIR & $\begin{array}{l}\text { Mandatory IR - Dummy variable equal to } 1 \text { if the firm issues an integrated report and is listed at the Johannesburg } \\
\text { Stock Exchange, and } 0 \text { otherwise. }\end{array}$ \\
\hline CV1 & LOSS & Firm profitability - Dummy variable equal to 1 if the firm reports negative income in the year, and 0 otherwise. \\
\hline $\mathrm{CV}_{2}$ & IFRS & $\begin{array}{l}\text { IFRS adoption-Dummy variable equal to } 1 \text { if thef inancial report of the firm is in compliance with IFRS, and } 0 \\
\text { otherwise. }\end{array}$ \\
\hline CV3 & SIZE & Firm size - The natural logarithm of a firm's total assets in US dollars at the end of the year. \\
\hline $\mathrm{CV} 4$ & HORIZON & $\begin{array}{l}\text { Forecast horizon - The median forecast horizon (the number of days between the earnings announcement date and } \\
\text { forecast date) of analyst forecasts for each firm each year. }\end{array}$ \\
\hline CV5 & FOLLOW & Analyst following - The natural logarithm of the number of analysts following the firm through the year. \\
\hline
\end{tabular}

Note. This table provides an overview of the dependent (DV), independent (IV) and control (CV) variables used in this study.

\subsection{Hypothesis Testing}

We use OLS regression models to test our hypotheses.

\subsubsection{Base Model}

We use the following conceptual base model to test our four hypotheses:

$$
\text { Forecast error }=f(\text { Integrated Reporting, Control variables })
$$

In more detail:

\section{Model hypothesis 1}

We use the following OLS regression model in order to test hypothesis 1, following Dhaliwal et al. (2012):

$$
\triangle \text { FERROR }_{i, t+1}=\beta_{0}+\beta_{1} \Delta I R_{i, t}+\beta_{2} \text { LOSS }_{i, t}+\beta_{3} I_{F R S_{i, t}}+\beta_{4} \operatorname{SIZE}_{i, t}+\beta_{5} \Delta \text { HORIZON }_{i, t}+\beta 6 \Delta \text { FOLLOW }_{i, t}+\varepsilon_{i, t}
$$

\section{Model hypothesis 2}

We use the following OLS regression model for hypothesis 2 :

$\triangle$ FERROR $_{i, t+1}=\beta_{0}+\beta_{1} \triangle$ ASSURIR $_{i, t}+\beta_{2}$ LOSS $_{i, t}+\beta_{3}$ IFRS $_{i, t}+\beta_{4} \operatorname{SIZE}_{i, t}+\beta_{5} \Delta$ HORIZON $_{i, t}+\beta_{6} \Delta F O L L O W_{i, t}+\varepsilon_{i, t}(4)$

Model hypothesis 3

We use the following OLS regression model to test hypothesis 3: 
$\triangle$ FERROR $_{i, t+1}=\beta_{0}+\beta_{1} \triangle A S S U R I R 4_{i, t}+\beta_{2} \operatorname{LOSS}_{i, t}+\beta_{3}$ IFRS $_{i, t}+\beta_{4} \operatorname{SIZE}_{i, t}+\beta_{5} \Delta \operatorname{HORIZON}_{i, t}+\beta_{6} \Delta F O L L O W_{i, t}+\varepsilon_{i, t}(5)$ Model hypothesis 4

We use the following OLS regression model for hypothesis 4 :

$\triangle$ FERROR $_{i, t+1}=\beta_{0}+\beta_{1} \Delta$ MANIR $_{i, t}+\beta_{2}$ LOSS $_{i, t}+\beta_{3}$ IFRS $_{i, t}+\beta_{4} \operatorname{SIZE}_{i, t}+\beta_{5} \Delta$ HORIZON $_{i, t}+\beta_{6} \Delta F O L L O W_{i, t}+\varepsilon_{i, t}(6)$

\section{Empirical Analysis}

\subsection{Descriptive Statistics}

All variables except the dummy variables (i.e. forecast error (FERROR), firm size (FSIZE), forecast horizon (HORIZON) and analyst following (FOLLOW) are winsorized at the 1st and 99th percentiles. Furthermore, the variables are checked for being normally distributed, linear, independent and homoscedastic.

Table 3 shows the descriptive summary statistics for all variables used in the regressions. The table displays the number of observations, mean, standard deviation and the first, second and third percentile.

The dependent variable FERROR has a mean of 0.02631 . This is the average forecast error of the total sample scaled by the share price. The mean of IR is 0.1066 , meaning that 10.7 percent of all observations had issued an integrated report. The mean of ASSURIR is 0.0570 , meaning that 5.7 percent of all observations contained an integrated report on which external assurance is provided. The mean of ASSURIR4 is 0.0427, meaning that 4.27 percent of all observations contained an integrated report on which external assurance is provided by a Big 4 audit firm. The difference between the mean of ASSURIR and ASSURIR4 is only 1.43 percent, which means that most external assurance is provided by a Big 4 audit firm. The mean of MANIR is 0.0262 , meaning that only 2.62 percent of all observations is listed at the JSE and thus is subject to mandatory Integrated Reporting.

Table 4 shows the distribution of observations for the independent variables IR, ASSURIR, ASSURIR4, and MANIR over the years 2013 until 2018. The number of observations is compared with the total sample and the percentage is presented in the table.

This gives us insights into how Integrated Reporting is evaluated. There were only 39 observations in 2018, of which 20.51 percent included an integrated report. Because of the sample size of 2018 and because not all data in 2018 were available, these percentages do not reliably reflect the data and are ignored. If we disregard the observations in 2018, there is no trend visible.

\subsection{Pearson Correlation Matrix}

The Pearson Correlation Matrix indicates that there is not strong correlation between the variables that we use. The independent variables: IR, ASSURIR, ASSURIR4, and MANIR are not used in the same regressions, thus the correlations between them are not relevant. The results of the correlation matrix are presented in Table 5.

\subsection{Regression Analysis}

Robust regressions are conducted in order to check each hypothesis. FERROR is the inverse measurement of analyst forecast accuracy. Therefore, the results of the regressions are considered to have a reverse effect on analyst forecast accuracy when analyzing the outcomes.

\subsubsection{Regression Results for Integrated Reporting}

The first regression analysis examines the relationship among forecast error (FERROR) and Integrated Reporting (IR). The results are presented in Table 6. The F-statistic is significant and equal to 16.92. The R-square is equal to 0.1993, which means that a considerable variation of forecast error remains unexplained.

In contrast to Hypothesis 1, the relation between FERROR and IR is insignificant and positive. Therefore, integrated reports do not seem to impact analyst forecast accuracy. Prior research suggests that it is more difficult to make a forecast for firms that report losses (Dhaliwal et al., 2012; Hope, 2003; Behn, Choi, \& Kang, 2008). The regression analysis indicates that there is indeed a positive and significant relation between the control variable LOSS and FERROR. The relation between IFRS and FERROR is not statistically significant even though it has a slight negative impact on the forecast error (p-value of 0.191). This result is not in line with prior literature that indicates a significant relationship. We can explain this phenomenon taking into account that the sample's size is relatively small. According to the results, the third control variable SIZE has a positive impact on FERROR in contrast with previous research. Therefore, the results of our regression analysis show that larger companies have higher forecast errors. The fourth control variable HORIZON does not affect FERROR.

This can be partially explained by the fact that forecast horizon is no more than one year. Finally, FOLLOW has a significant negative impact on FERROR as expected from prior studies (Behn et al., 2008; Dhaliwal et al., 2012; 
Hope, 2003). That means that analyst forecast accuracy increases when more analysts follow the company.

Table 3. Descriptive statistics

\begin{tabular}{lcccccc}
\hline Variable & $\mathrm{N}$ & $\mathrm{Mean}$ & $\mathrm{SD}$ & $\mathrm{p} 25$ & Median & $\mathrm{p} 75$ \\
FERROR & 1755 & 0.026310 & 0.069962 & 0.002196 & 0.006587 & 0.018248 \\
IR & 1755 & 0.106553 & 0.308632 & 0 & 0 & 0 \\
ASSURIR & 1755 & 0.056980 & 0.231871 & 0 & 0 & 0 \\
ASSURIR4 & 1755 & 0.042735 & 0.202317 & 0 & 0 & 0 \\
MANIR & 1755 & 0.026211 & 0.159807 & 0 & 0 & 0 \\
LOSS & 1755 & 0.100285 & 0.300465 & 0 & 0 & 0 \\
IFRS & 1755 & 0.687180 & 0.463774 & 0 & 1 & 1 \\
SIZE & 1755 & 8.208035 & 1.602471 & 7.239308 & 8.181986 & 9.090442 \\
HORIZON & 1755 & 205.839 & 42.49213 & 183 & 202 & 225.5 \\
FOLLOW & 1755 & 2.135328 & 0.966003 & 1.609438 & 2.302585 & 2.833213 \\
\hline
\end{tabular}

Note. This table provides the number of observations, mean, standard deviation, first quartile, median and third quartile of the regression variables. Table 3 provides an overview of all variables.

Table 3 contains the descriptive summary statistics for the variables that are used in the regressions. The observations of the final sample are 1755 and they are from 698 unique companies. The dependent variable FERROR has a mean of 0.02631 . This is the average forecast error of the total sample scaled by the share price.

Table 4. Unique observations of independent variables

\begin{tabular}{lccccccccc}
\hline Year & N total sample & N IR & Percentage & N ASSURIR & Percentage & N ASSURIR4 & Percentage & N MANIR & Percentage \\
\hline 2013 & 227 & 25 & $11.01 \%$ & 11 & $4.85 \%$ & 8 & $3.52 \%$ & 7 & $3.08 \%$ \\
2014 & 303 & 27 & $8.91 \%$ & 17 & $5.61 \%$ & 13 & $4.29 \%$ & 12 & $3.96 \%$ \\
2015 & 364 & 41 & $11.26 \%$ & 22 & $6.04 \%$ & 17 & $4.67 \%$ & 14 & $3.85 \%$ \\
2016 & 425 & 43 & $10.12 \%$ & 23 & $5.41 \%$ & 18 & $4.24 \%$ & 7 & $1.65 \%$ \\
2017 & 397 & 43 & $10.83 \%$ & 22 & $5.54 \%$ & 15 & $3.78 \%$ & 5 & $1.26 \%$ \\
2018 & 39 & 8 & $20.51 \%$ & 5 & $12.82 \%$ & 4 & $10.26 \%$ & 1 & $2.56 \%$ \\
Total & 1755 & 187 & $10.66 \%$ & 100 & $5.70 \%$ & 75 & $4.27 \%$ & 46 & $2.62 \%$ \\
\hline
\end{tabular}

Note. This table provides the number of unique observations for Integrated Reporting, external assurance, external assurance by a Big 4 audit firm, and mandatory Integrated Reporting compared to the total number of observations. Table 3 provides an overview of all variables.

Table 4 shows the distribution of observations for the independent variables IR, ASSURIR, ASSURIR4, and MANIR over the years 2013 until 2018. The number of observations is compared with the total sample and the percentage is presented in the table. This gives us insight into how Integrated Reporting is evaluating.

Table 5 shows that there is no multicollinearity in the sample, which means that none of the variables is correlated strongly with the other variables. Thus, variables that are used are totally appropriate and they do not create any potential problems in the regressions.

Table 5. Pearson correlation matrix

\begin{tabular}{|c|c|c|c|c|c|c|c|c|c|c|c|}
\hline & Pred.sign & FERROR & IR & ASSURIR & ASSURIR4 & MANIR & LOSS & IFRS & SIZE & HORIZON & FOLLOW \\
\hline FERROR & & 1 & & & & & & & & & \\
\hline \multirow[t]{2}{*}{ IR } & - & 0.0003 & 1 & & & & & & & & \\
\hline & & 0.9900 & & & & & & & & & \\
\hline \multirow{2}{*}{ ASSURIR } & - & 0.0280 & 0.7118 & 1 & & & & & & & \\
\hline & & 0.2407 & $0.0000^{* * * *}$ & & & & & & & & \\
\hline \multirow[t]{2}{*}{ ASSURIR } & - & 0.0492 & 0.6118 & 0.8596 & 1 & & & & & & \\
\hline & & $0.0394 * *$ & $0.0000^{* * * *}$ & $0.0000^{* * * *}$ & & & & & & & \\
\hline \multirow[t]{2}{*}{ MANIR } & - & -0.0175 & 0.4751 & 0.3443 & 0.3533 & 1 & & & & & \\
\hline & & 0.4638 & $0.0000^{* * * *}$ & $0.0000^{* * * *}$ & $0.0000^{* * *}$ & & & & & & \\
\hline \multirow[t]{2}{*}{ LOSS } & + & 0.4152 & -0.0169 & 0.0161 & 0.0232 & 0.0165 & 1 & & & & \\
\hline & & $0.0000^{* * *}$ & 0.4785 & 0.4994 & 0.3304 & 0.4906 & & & & & \\
\hline \multirow[t]{2}{*}{ IFRS } & - & -0.0094 & 0.1812 & 0.1393 & 0.1304 & 0.1030 & 0.0821 & 1 & & & \\
\hline & & 0.6934 & $0.0000^{* * * *}$ & $0.0000 * * *$ & $0.0000^{* * * *}$ & $0.0000 * * *$ & $0.0006 * * *$ & & & & \\
\hline
\end{tabular}




\begin{tabular}{cccccccccccc}
\hline SIZE & - & -0.0573 & -0.0217 & 0.0151 & 0.0068 & -0.1105 & -0.0907 & -0.0823 & 1 & & \\
& & $0.0164 * *$ & 0.3644 & 0.5273 & 0.7755 & $0.0000^{* * *}$ & $0.0001^{* * *}$ & $0.0006^{* * *}$ & & & \\
HORIZON & + & -0.0013 & -0.0432 & -0.0320 & -0.0490 & -0.0224 & -0.0042 & -0.0389 & 0.0033 & 1 & \\
& & 0.9551 & $0.0705^{*}$ & 0.1800 & $0.0400^{* *}$ & 0.3487 & 0.8588 & 0.1036 & 0.8899 & & \\
FOLLOW & -0.1771 & -0.0690 & -0.0205 & -0.0445 & -0.1334 & -0.0809 & 0.0461 & 0.5614 & 0.0357 & 1 \\
& & $-0.0000^{* * *}$ & $0.0038^{* * *}$ & 0.3902 & $0.0621^{*}$ & $0.0000^{* * *}$ & $0.0007 * * *$ & $0.0535^{*}$ & $0.0000^{* * *}$ & 0.1345 & \\
\hline
\end{tabular}

Note. This table provides the Pearson correlation between all variables.

*,**, *** indicate that the coefficients are significant at the 10 percent, 5 percent, and 1 percent levels, respectively.

The sample consists of 1755 observations of 698 unique firms. The variables FERROR, SIZE, HORIZON, and FOLLOW are winsorized at the 1st and 99th percentiles to filter out potential outliers. Table 3 provides an overview of all variables.

Table 6 presents the first regression that examines the association between forecast error and Integrated Reporting. When we examine R-square we find that the model explains 19.93 percent of the change in forecast error. The first hypothesis is rejected because there is not a significant relationship among analyst forecast error and Integrating Reporting.

Table 6. Linear regression model 1:

\begin{tabular}{|c|c|c|c|c|c|}
\hline FERROR & Coefficient & P-value & & & \\
\hline IR & 0.000261 & 0.961 & $\mathrm{~N}$ & $=$ & 1.755 \\
\hline LOSS & 0.095419 & $0.000^{* * * *}$ & $\mathrm{~F}(6.1748)$ & $=$ & 16.92 \\
\hline IFRS & -0.004120 & 0.191 & Prob $>F$ & $=$ & $0.000 * * *$ \\
\hline SIZE & 0.003685 & $0.002 * * *$ & R-squared & $=$ & 0.1993 \\
\hline HORIZON & 0.000010 & 0.816 & Root MSE & $=$ & 0.06271 \\
\hline FOLLOW & -0.013774 & $0.000 * * *$ & & & \\
\hline
\end{tabular}

Note. This table provides the results of the linear regression analysis for the first hypothesis. ${ }^{*}, * *, * * *$ indicate that the coefficients are significant at the 10 percent, 5 percent, and 1 percent levels, respectively. Table 3 provides an overview of all variables.

\subsubsection{Regression Results for External Assurance of Integrated Reporting}

The second regression analysis examines the relationship between forecast error (FERROR) and external assurance on Integrated Reporting (ASSURIR). The results are presented in Table 7. The value of the F-statistic is 16.9 and R-square is 0.1997 .

According to Hypothesis 2, the relation between FERROR and ASSURIR is expected to be significant and negative. Nevertheless, the regression outcome indicates no statistically significant relation between these two variables. Our study suggests that external assurance on integrated reports does not affect analyst forecast accuracy. Therefore, we reject Hypothesis 2.

Table 7. Linear regression model 2:

\begin{tabular}{|c|c|c|c|c|c|}
\hline FERROR & Coefficient & $\mathrm{P}$-value & & & \\
\hline ASSURIR & 0.006238 & 0.481 & $\mathrm{~N}$ & $=$ & 1.755 \\
\hline LOSS & 0.095386 & $0.000 * * *$ & $\mathrm{~F}(6.1748)$ & $=$ & 16.90 \\
\hline IFRS & -0.004540 & 0.146 & Prob $>F$ & $=$ & $0.000 * * *$ \\
\hline SIZE & 0.003632 & $0.002 * * *$ & R-squared & $=$ & 0.1997 \\
\hline HORIZON & 0.000011 & 0.802 & Root MSE & $=$ & 0.0627 \\
\hline FOLLOW & -0.013690 & $0.000 * * *$ & & & \\
\hline
\end{tabular}

Note. This table provides the results of the linear regression analysis for the second hypothesis. *, **, *** indicate that the coefficients are significant at the 10 percent, 5 percent, and 1 percent levels, respectively. Table 3 provides an overview of all variables.

Previous studies have shown that analyst forecast accuracy increases when there is external assurance on integrated reports because the quality of reports is considered higher (Pflugrath et al., 2011; Behn et al., 2008; Casey \& Grenier, 2015). The results of this paper are not line with the literature and an explanation to this may be the sample content. In the sample different kinds of assurance are included. GRI provides information on whether there is external assurance, but of different types; The level of attestation and the scope of assurance differ across the sample and this could have resulted in the differences with prior literature. 
Control variables, LOSS, SIZE and FOLLOW have a significant relationship with FERROR. LOSS and SIZE have a positive impact while FOLLOW has a negative impact on forecast error. On the contrary, IFRS and HORIZON are not statistically significant. However, IFRS has a negative impact with a p-value of 0.146 . LOSS, IFRS and FOLLOW are in line with expectations, while the results for SIZE and HORIZON are not in line with prior studies.

\subsubsection{Regression Results for Assurance of Integrated Reporting Provided by a Big 4 Audit Firm}

In the third regression we examine the relationship between the forecast error (FERROR) and external assurance on Integrated Reporting, provided by a Big 4 audit firm (ASSURIR4). The results of the regression are presented in Table 8. The F-statistic is significant and equal with 16.9. R-square is 0.2005 .

According to Hypothesis 3, the relation between FERROR and ASSURIR4 is expected to be significant and negative. Analyst forecast accuracy is expected to increase when there is external assurance by a Big 4 audit firm (Deloitte, PwC, EY and KPMG). However, the regression results present an insignificant relation between FERROR and ASSURIR4 and therefore Hypothesis 3 is rejected.

There are not previous studies suggesting that external assurance on integrated reports by a Big 4 audit firm, will increase analyst forecast accuracy. However, literature indicates that external assurance increases disclosure quality and thus, analyst forecast accuracy (Hope, 2003; Lang \& Lundholm, 1996; Behn et al., 2018). The positive impact of external assurance was expected to be even stronger when provided by a Big 4 audit firm. Our results do not support these expectations. On the contrary, we observe a slight positive relation between FERROR and ASSURIR4. This could imply that the reports that are assured by a Big 4 audit firm are more complex and hence, harder to process. Due to this fact analyst forecast accuracy is decreased (Plumlee, 2003; Lehavy et al., 2011).

Table 8. Linear regression model 3:

\begin{tabular}{|c|c|c|c|c|c|}
\hline$\overline{\text { FERROR }}$ & Coefficient & P-value & & & \\
\hline ASSURIR4 & 0.012201 & 0.290 & $\mathrm{~N}$ & $=$ & 1.755 \\
\hline LOSS & 0.095319 & $0.000^{* * *} *$ & $\mathrm{~F}(6.1748)$ & $=$ & 16.90 \\
\hline IFRS & -0.004818 & 0.122 & Prob $>$ F & $=$ & $0.000^{* * *}$ \\
\hline SIZE & 0.003583 & $0.002 * * *$ & $\mathrm{R}$-squared & $=$ & 0.2005 \\
\hline HORIZON & 0.000012 & 0.775 & Root MSE & $=$ & 0.06266 \\
\hline FOLLOW & -0.013561 & $0.000^{* * * *}$ & & & \\
\hline
\end{tabular}

Note. This table provides the results of the linear regression analysis for the third hypothesis. $*, * *, * * *$ indicate that the coefficients are significant at the 10 percent, 5 percent, and 1 percent levels, respectively. Table 3 provides an overview of all variables.

LOSS, SIZE and FOLLOW have a significant relation with FERROR. LOSS and SIZE have a positive impact, while FOLLOW has a negative impact on forecast error. IFRS and HORIZON are not strongly significant related to FERROR. IFRS however, has a negative impact on FERROR with a p-value of 0.122. The outcome for LOSS, IFRS and FOLLOW are in line with literature. The outcome for SIZE and HORIZON are not in line with the expectations.

\subsubsection{Regression Results for Mandatory Integrated Reporting}

In our fourth regression we examine the relationship between forecast error (FERROR) and mandatory Integrated Reporting (MANIR). Table 9 presents the results of this regression. The F-statistic is significant and R-square is 0.2007 .

Table 9. Linear regression model 4:

\begin{tabular}{|c|c|c|c|c|c|}
\hline FERROR & Coefficient & P-value & & & \\
\hline MANIR & -0.016884 & $0.010 * * *$ & $\mathrm{~N}$ & $=$ & 1.755 \\
\hline LOSS & 0.095364 & $0.000 * * *$ & $\mathrm{~F}(6.1748)$ & $=$ & 16.99 \\
\hline IFRS & -0.003474 & 0.276 & Prob $>F$ & $=$ & $0.000 * * *$ \\
\hline SIZE & 0.003627 & $0.002 * * *$ & R-squared & $=$ & 0.2007 \\
\hline HORIZON & 0.000009 & 0.833 & Root MSE & $=$ & 0.06266 \\
\hline FOLLOW & -0.014112 & $0.000 * * *$ & & & \\
\hline
\end{tabular}

Note. This table provides the results of the linear regression analysis for the fourth hypothesis. *,**, *** indicate that the coefficients are significant at the 10 percent, 5 percent, and 1 percent levels, respectively. Table 3 provides an overview of all variables. 
In hypothesis 4 we expect a significant negative association between FERROR and MANIR. Consequently, in case that mandatory Integrated Reporting is implemented, analyst forecast accuracy is increased. The regression results confirm the validity of this hypothesis. FERROR and MANIR are negatively associated with a statistically significant p-value.

The results of this regression are in line with the study of Bernardi and Stark (2016) who indicate increased analyst forecast accuracy following the mandatory implementation of Integrated Reporting.

LOSS, SIZE and FOLLOW have a significant relation with FERROR. LOSS and SIZE have a positive impact, while FOLLOW has a negative impact on forecast error. IFRS and HORIZON are not strongly significant related to FERROR. The outcome for LOSS, IFRS and FOLLOW are in line with previous literature. The results for SIZE and HORIZON are not the expected.

\subsection{Robustness Check}

Following Cheong and Thomas (2011) we used unscaled forecast errors as an alternative proxy for our dependent variable. Cheong and Thomas (2011) argue that unscaled analyst forecast errors vary little for U.S. firms and a number of other large markets, so they do not divide it with share price or actual earnings. Our four hypotheses are also tested by proxying the forecast error as the difference between the median analyst earnings forecast and the actual earnings per share in U.S. dollar (FERROR2).

The results for $\mathrm{H} 1, \mathrm{H} 2, \mathrm{H} 3$, and $\mathrm{H} 4$ hold with the alternative dependent variable. This supports the conclusion that Integrated Reporting has a statistically significant effect on analyst forecast accuracy only when the implementation is mandatory. The results of the regressions conducted for the robustness check can be found in Appendix A, Table 11. Robustness test hypothesis 1; Table 12. Robustness test hypothesis 2; Table 13. Robustness test hypothesis 3; and Table 14. Robustness test hypothesis 4.

\section{Discussion and Conclusions}

This study is motivated by the limited empirical evidence regarding the effect of Integrated Reporting. Traditional financial reporting has been challenged because it is perceived not to satisfy the information needs of stakeholders to assess an organization's past and future performance. Integrated Reporting is supposed to fill this gap, however, limited evidence of its effect on the capital market is present. In our study we document that there is no significant relationship between analyst forecast accuracy and Integrated Reporting, external assurance on Integrated Reporting and external assurance by a Big 4 audit firm on Integrated Reporting. These results contradict expectations from prior research. However we find, analyst forecast accuracy being positively related with the mandatory implementation of Integrated Reporting. Consequently, only mandatory integrated reports provide information valuable for investors. This outcome is in line with previous studies that examine the relation between analyst forecast accuracy and mandatory implementation of Integrated Reporting.

A possible explanation for this could be that the quality of an integrated report is higher when its implementation is obligatory. Higher quality leads to a reduction of information asymmetry and to an increase of analyst forecast accuracy. Firms that are obliged to issue integrated reports are more familiar with reporting and therefore the information that they provide is of higher quality.

\section{Study Limitations and Recommendations}

This study provides some important insights relative to Integrated Reporting and analyst forecast accuracy. Taking into account that the empirical research on Integrated Reporting is limited, our paper examines several aspects of the implementation of Integrated Reporting and their impact on analyst error which is the inverse measurement of analyst forecast accuracy.

Our analysis and results are limited to the size of our sample. The GRI database provides only the company name as an identifier for each of the entities involved. As a result, it is difficult to merge with other databases as the I/B/E/S database and Compustat Global. Our sample size decreased drastically after that merging. Another limitation is the voluntary implementation of integrated reports. Integrated reports in the GRI database are selfdeclared as such (“...for those reports labeled as 'integrated', the reporting organization has included both non-financial disclosures and financial disclosures, beyond basic economic information i.e., as required under the EC category of the GRI Guidelines or the GRI Standards 200 series, in a single report" GRI, 2019), so the information provided is not uniform and the quality is not always high. The International Integrated Reporting Framework has issued guidelines but if the reports do not comply with this framework, theory might not hold. Finally, the number of control variables consists a limitation for this study because there are many factors that it is possible to affect analyst forecast accuracy but they are not included in our paper. 
Future research could utilize the larger availability of data points and also examine more control variables to test if existing theory holds. In addition, future research could examine the reason why there is difference between voluntary and mandatory implementation of Integrated Reporting. Taking into account that mandatory Integrated Reporting is implemented only in South Africa, a cross country analysis could provide more insights.

\section{References}

Barth, M. E., Cahan, S. F., Chen, L., \& Venter, E. R. (2017). The economic consequences associated with integrated report quality: Capital market and real effects. Accounting, Organizations and Society, 62(2017), 43-64. https://doi.org/10.1016/j.aos.2017.08.005

Behn, B. K., Choi, J. H., \& Kang, T. (2008). Audit quality and properties of analyst earnings forecasts. The Accounting Review, 83(2), 327-349. https://doi.org/10.2308/accr.2008.83.2.327

Bernardi, C., \& Stark, A. W. (2016). Environmental, social and governance disclosure, integrated reporting, and the accuracy of analyst forecasts. The British Accounting Review, 50(1), 16-31. https://doi.org/10.1016/j.bar.2016.10.001

Beyer, A., Cohen, D. A., Lys, T. Z., \& Walther, B. R. (2010). The financial reporting environment: Review of the recent literature. Journal of Accounting and Economics, 50(2-3), 296-343. https://doi.org/10.1016/j.jacceco.2010.10.003

Brown, L. D., Call, A. C., Clement, M. B., \& Sharp, N. Y. (2015). Inside the "black box" of sell-side financial analysts. Journal of Accounting Research, 53(1), 1-47. https://doi.org/10.1111/1475-679X.12067

Caglio, A., Melloni, G., \& Perego, P. (2019). Informational Content and Assurance of Textual Disclosures: Evidence on Integrated Reporting. European Accounting Review. https://doi.org/10.1080/09638180.2019.1677486

Cheng, M., Green, W., Conradie, P., Konishi, N., \& Romi, A. (2014). The International Integrated Reporting Framework: Key Issues and Future Research Opportunities. Journal of International Financial Management \& Accounting, 25(1), 90-119. https://doi.org/10.1111/jifm.12015

Cheong, F. S., \& Thomas, J. (2011). Why do EPS forecast error and dispersion not vary with scale? Implications for analyst and managerial behavior. Journal of Accounting Research, 49(2), 359-401. https://doi.org/10.1111/j.1475-679X.2010.00387.x

Cohen, J. R., Holder-Webb, L. L., Nath, L., \& Wood, D. (2012). Corporate reporting of nonfinancial leading indicators of economic performance and sustainability. Accounting Horizons, 26(1), 65-90. https://doi.org/10.2308/acch-50073

Dhaliwal, D. S., Li, O. Z., Tsang, A., \& Yang, Y. G. (2011). Voluntary nonfinancial disclosure and the cost of equity capital: The initiation of corporate social responsibility reporting. The Accounting Review, 86(1), 59-100. https://doi.org/10.2308/accr.00000005

Dhaliwal, D. S., Radhakrishnan, S., Tsang, A., \& Yang, Y. G. (2012). Nonfinancial Disclosure and Analyst Forecast Accuracy: International Evidence on Corporate Social Responsibility Disclosure. American Accounting Association, 87(3), 723-759. https://doi.org/10.2308/accr-10218

Dumay, J., Bernardi, C., Guthrie, J., \& Demartini, P. (2016, September). Integrated reporting: A structured literature review. Accounting Forum, 40(3), 166-185. https://doi.org/10.1016/j.accfor.2016.06.001

Eccles, R. G., \& G. Serafeim. (2014). Corporate and Integrated Reporting: A Functional Perspective. Harvard Business School.

Eccles, R. G., \& Michael, K. (2010). One Report: Integrated Reporting for a Sustainable Strategy. New York: John Wiley \& Sons.

Frankel, R., Kothari, S. P., \& Weber, J. (2006). Determinants of the informativeness of analyst research. Journal of Accounting \& Economics, 41(1), 29-54. https://doi.org/10.1016/j.jacceco.2005.10.004

Gleason, C. A., \& Lee, C. M. (2003). Analyst forecast revisions and market price discovery. The Accounting Review, 78(1), 193-225. https://doi.org/10.2308/accr.2003.78.1.193

Healy, P. M., \& Palepu, K. G. (2001). Information asymmetry, corporate disclosure and the capital markets: A review of the empirical disclosure literature. Journal of Accounting and Economics, 31(1), 405-440. https://doi.org/10.1016/S0165-4101(01)00018-0

Hodge, F. D. (2001). Hyperlinking unaudited information to audited financial statements: Effects on investor 
judgments. The Accounting Review, 76(4), 675-691. https://doi.org/10.2308/accr.2001.76.4.675

Hope, O. (2003). Disclosure Practices, Enforcement of Accounting Standards, and Analysts' Forecast Accuracy: An International Study. Journal of Accounting Research, 41(2), 235-272. https://doi.org/10.1111/1475-679X.00102

Humphrey, C., O’Dwyer, B, \& Unerman, J. (2017). Re-theorizing the configuration of organizational fields: The IIRC and the pursuit of "Enlightened" corporate reporting. Accounting and Business Research, 47(1), 30-63. https://doi.org/10.1080/00014788.2016.1198683

International Integrated Reporting Council (IIRC). (2013a). The International Integrated Reporting Framework. Retrieved

from http://integratedreporting.org/wp-content/uploads/2015/03/13-12-08-THE-INTERNATIONAL-IR-FRAME WORK-2-1.pdf

International Integrated Reporting Council (IIRC). (2013b). Consultation Draft of the International Framework. Retrieved from https://integratedreporting.org/wp-content/uploads/2013/03/Consultation-Draft-of-the-InternationalIRFrame work.pdf

International Integrated Reporting Council (IIRC). (2017). International Framework Implementation Feedback: Invitation to comment. International Integrated Reporting Council London. Retrieved from https://integratedreporting.org/wp-content/uploads/2017/02/Invitation-to-Comment_27-Feb-2017.pdf

Jensen, M. C., \& Meckling, W. H. (1976). Theory of the Firm: Managerial Behavior, Agency Costs and Ownership Structure. Journal of Financial Economics, 3(4), 305-360. https://doi.org/10.1016/0304-405X(76)90026-X

Kasznik, R., \& McNichols, M. F. (2002). Does meeting earnings expectations matter? Evidence from analyst forecast revisions and share prices. Journal of Accounting Research, 40(3), 727-759. https://doi.org/10.1111/1475-679X.00069

Kelton, A. S., Pennington, R. R., \& Tuttle, B. M. (2010). The effects of information presentation format on judgment and decision making: A review of the information systems research. Journal of Information Systems, 24(2), 79-105. https://doi.org/10.2308/jis.2010.24.2.79

Khurana, K. I., \& Raman, K. K. (2004). Litigation risk and the financial reporting credibility of Big 4 versus NonBig 4 audits: Evidence from Anglo-American countries. The Accounting Review 79(2), 473-495. https://doi.org/10.2308/accr.2004.79.2.473

Koonce, L., \& Mercer, M. (2005). Using psychology theories in archival financial accounting research (January 5, 2005). McCombs Research Paper Series No. ACC-01-05. http://dx.doi.org/10.2139/ssrn.311105

Lang, M. H., \& Lundholm, R. J. (1996). Corporate Disclosure Policy and Analyst Behavior. The Accounting Review, 71(4), 467-492.

Lehavy, R., Li, F., \& Merkley, K. (2011). The effect of annual report readability on analyst following and the properties of their earnings forecasts. The Accounting Review, 86(3), 1087-1115. https://doi.org/10.2308/accr.00000043

Pistoni, A., Songini, L., \& Bavagnoli, F. (2018). Integrated Reporting Quality: An Empirical Analysis. Corporate Social Responsibility and Environmental Management, 25(4), 489-507. https://doi.org/10.1002/csr.1474

Plumlee, M. A. (2003). The effect of information complexity on analysts' use of that information. The Accounting Review, 78(1), 275-296. https://doi.org/10.2308/accr.2003.78.1.275

Rajgopal, S., Shevlin, T., \& Venkatachalam, M. (2003). Does the stock market fully appreciate the implications of leading indicators for future earnings? Evidence from order backlog. Review of Accounting Studies, 8(4), 461-492. https://doi.org/10.1023/A:1027364031775

Simnett, R., Vanstraelen, A., \& Chua, W. F. (2009). Assurance on sustainability reports: An international comparison. The Accounting Review, 84(3), 937-967. https://doi.org/10.2308/accr.2009.84.3.937

Zhou, S., Simnett, R., \& Green, W. (2017). Does Integrated Reporting Matter to the Capital Market? Abacus, 53(1). https://doi.org/10.1111/abac.12104 


\section{Appendix}

Table 10. Robustness test hypothesis 1

\begin{tabular}{lccccc}
\hline FERROR2 & Coefficient & P-value & & & \\
IR & -0.0252409 & 0.540 & $\mathrm{~N}$ & $=$ & 1.755 \\
LOSS & 0.3452557 & $0.000^{* * *}$ & $\mathrm{~F}(6.1748)$ & $=$ & 13.08 \\
IFRS & 0.1209052 & $0.000 * * *$ & Prob $>\mathrm{F}$ & $=$ & $0.000^{* * *}$ \\
SIZE & 0.0350761 & $0.000^{* * *}$ & R-squared & $=$ & 0.0661 \\
HORIZON & -0.0004350 & $0.084 *$ & Root MSE & $=$ & 0.48105 \\
FOLLOW & -0.0130048 & 0,453 & & & \\
\hline
\end{tabular}

This table provides the results of the linear regression analysis with an alternative dependent variable, FERROR2, for the first hypothesis. *,**, *** indicate that the coefficients are significant at the 10 percent, 5 percent, and 1 percent levels, respectively. Table 3 provides an overview of all variables.

Table 11. Robustness test hypothesis 2

\begin{tabular}{llcccc}
\hline FERROR2 & Coefficient & P-value & & \\
\hline ASSURIR & -0.0120148 & 0.817 & $\mathrm{~N}$ & $=$ & 1.755 \\
LOSS & 0.3462573 & $0.000^{* * *}$ & $\mathrm{~F}(6.1748)$ & $=$ & 13.04 \\
IFRS & 0.1185512 & $0.000^{* * *}$ & Prob $>\mathrm{F}$ & $=0.000^{* * *}$ \\
SIZE & 0.0349302 & $0.000^{* * *}$ & R-squared & $=$ & 0.0659 \\
HORIZON & -0.0004307 & $0.087^{*}$ & Root MSE & $=$ & 0.4811 \\
FOLLOW & -0.0123013 & 0.478 & & \\
\hline
\end{tabular}

This table provides the results of the linear regression analysis with an alternative dependent variable, FERROR2, for the second hypothesis. *, **, *** indicate that the coefficients are significant at the 10 percent, 5 percent, and 1 percent levels, respectively. Table 3 provides an overview of all variables.

Table 12. Robustness test hypothesis 3

\begin{tabular}{lccccc}
\hline FERROR2 & Coefficient & P-value & & & \\
\hline ASSURIR4 & 0.0147618 & 0.821 & $\mathrm{~N}$ & $=$ & 1.755 \\
LOSS & 0.3461045 & $0.000^{* * *}$ & $\mathrm{~F}(6.1748)$ & $=$ & 13.06 \\
IFRS & 0.1167895 & $0.000^{* * *}$ & Prob $>\mathrm{F}$ & $=$ & $0.000^{* * *}$ \\
SIZE & 0.0346965 & $0.000^{* * *}$ & R-squared & $=$ & 0.0659 \\
HORIZON & -0.0004262 & $0.090^{*}$ & Root MSE & $=$ & 0.4811
\end{tabular}

FOLLOW -0.0118586

This table provides the results of the linear regression analysis with an alternative dependent variable, FERROR2, for the third hypothesis. *, $* *$, *** indicate that the coefficients are significant at the 10 percent, 5 percent, and 1 percent levels, respectively. Table 3 provides an overview of all variables.

Table 13. Robustness test hypothesis 4

\begin{tabular}{|c|c|c|c|c|c|}
\hline FERROR2 & Coefficient & P-value & & & \\
\hline MANIR & -0.1851482 & $0.000 * * *$ & $\mathrm{~N}$ & $=$ & 1.755 \\
\hline LOSS & 0.3457161 & $0.000 * * *$ & $\mathrm{~F}(6,1748)$ & $=$ & 15.04 \\
\hline IFRS & 0.1243955 & $0.000 * * *$ & Prob $>$ F & $=$ & $0.000 * * *$ \\
\hline SIZE & 0.0341572 & $0.000 * * *$ & $\mathrm{R}$-squared & $=$ & 0.0693 \\
\hline HORIZON & -0.0004388 & $0.081^{*}$ & Root MSE & $=$ & 0.48022 \\
\hline FOLLOW & -0.0157391 & 0.371 & & & \\
\hline
\end{tabular}

This table provides the results of the linear regression analysis with an alternative dependent variable, FERROR2, for the fourth hypothesis. *, **, *** indicate that the coefficients are significant at the 10 percent, 5 percent, and 1 percent levels, respectively. Table 3 provides an overview of all variables.

\section{Copyrights}

Copyright for this article is retained by the author(s), with first publication rights granted to the journal.

This is an open-access article distributed under the terms and conditions of the Creative Commons Attribution license (http://creativecommons.org/licenses/by/4.0/). 